\title{
Inclusion of a fermented fish by-product meal in guinea fowl (Numida meleagris) diets: performance and carcass quality ${ }^{1}$
}

\author{
Héctor L. Santiago-Anadón ${ }^{2}$, Mireille Argüelles ${ }^{3}$ \\ and Abner A. Rodríguez ${ }^{4}$
}

J. Agric. Univ. P.R. 88(3-4):145-154 (2004)

\begin{abstract}
Guinea fowl (Numida meleagris) is a poultry species suitable for use in meat production to expand and diversify the local poultry industry because of its advantages of high consumer acceptance, resistance to common poultry diseases, and tolerance to poor management conditions. However, the poor feed conversion of this species increases feed costs and limits production. To reduce feed costs it is imperative to find locally available feedstuffs of low cost but with adequate nutritional value. The use of a fermented fish by-product meal (FFBPM) as a protein source in guinea diets could satisfy these criteria and reduce feed costs. This study with 180 birds was undertaken to evaluate the effects of the inclusion of a FFBPM in guinea diets on productive performance and carcass quality. Treatments consisted of FFBPM inclusion at levels of 0 (control), 5 , and $10 \%$ in each of the starter, grower, and finisher diets. Feed and birds were weighed at 0,35 , 63 , and $84 \mathrm{~d}$ to determine body weight (BW) and feed conversion. At $84 \mathrm{~d}$, half the birds of each treatment were processed for evaluating carcass composition and determining yields of carcass and major cuts. Fasted live body weights, and plucked and dressed carcass weights were recorded and yields calculated. No significant differences in BW were observed among treatments at 0,63 , and $84 \mathrm{~d}$. At $35 \mathrm{~d}, \mathrm{BW}$ was lower $(\mathrm{P}<0.05)$ in birds with a $10 \%$ FFBPM inclusion. Feed conversion at $35 \mathrm{~d}$ was also higher with $10 \%$ FFBPM and lower in control birds, whereas those receiving $5 \%$ FFBPM did not differ from those of the other treatments. Birds fed 10\% FFBPM showed significantly lower live, plucked, and dressed weights than those of the control and those fed 5\% FFBPM. No differences among treatments were observed in yields of dressed carcass, major cuts, and the proportions of flesh, skin, and bone. However, the percentage of abdominal fats was significantly lower in birds fed a 10\% FFBPM than in birds of the control and in those fed the 5\% FFBPM level. The results of this study indicate that the inclusion of up to $5 \%$ FFBPM in guinea diets has no detrimental effect on bird performance and carcass quality. Thus, FFBPM could be a valuable feed ingredient to supply part of the dietary protein requirements of guinea fowl.
\end{abstract}

Key words: guinea fowl, growth, fermented fish, carcass quality

${ }^{1}$ Manuscript submitted to Editorial Board 27 February 2004.

${ }^{2}$ Assistant Researcher, Department of Animal Industry, Agricultural Experiment Station, University of Puerto Rico, P.O. Box 9030, Mayagüez, P.R. 00681-9030.

${ }^{3}$ Graduate Student, Department of Animal Industry.

${ }^{4}$ Associate Professor, Department of Animal Industry, University of Puerto Rico, P.O. Box 9030, Mayagüez, P.R. 00681-9030. 


\section{RESUMEN}

Inclusión de un producto fermentado de pescado en la dieta de guineas (Numida meleagris): desempeño productivo y calidad de la carcasa

La crianza de guinea (Numida meleagris) es una alternativa viable para aumentar la producción local de carne de aves debido a su buena aceptación por el consumidor, resistencia a enfermedades y tolerancia a condiciones de manejo adversas. Sin embargo, la pobre conversión alimenticia de estas aves aumenta los costos de alimentación, limitando su producción. Para reducir dichos costos es necesario utilizar ingredientes poco costosos pero de valor nutricional adecuado. La utilización de un subproducto fermentado de pescado (SPFP) como fuente de proteína en dietas de guinea podría satisfacer estos requisitos y reducir los costos de alimentación. EI propósito de esta investigación fue evaluar el efecto de la inclusión de SPFP en dietas de guineas sobre el desempeño productivo y la calidad de la carcasa. Los tratamientos consistieron en la inclusión de 0, 5 y 10\% SPFP en las dietas de iniciación, crecimiento y terminación. Se pesó el alimento y las aves a los $0,35,63$ y 84 d para determinar el peso corporal y la conversión alimenticia. A los 84 d, se procesaron 90 aves para evaluar la calidad de la carcasa y determinar el rendimiento de la misma y sus componentes principales. Se midió su peso vivo en ayuno, peso desplumado y peso listo para cocinar y se calcularon los rendimientos. No se observaron diferencias significativas en peso corporal entre los tratamientos a los 0,63 y $84 \mathrm{~d}$. A los $35 \mathrm{~d}$ el peso corporal fue menor $(P<0.05)$ en aves a las que se les suministró un $10 \%$ SPFP. La conversión alimenticia a los $35 \mathrm{~d}$ fue mayor en aves a las que se les suministró $10 \%$ SPFP y menor en las aves control, mientras la de aquellas a las que se les suministró $5 \%$ SPFP fue similar a la del resto de los tratamientos. Las aves con $10 \%$ SPFP registraron un peso vivo, desplumado y listo para cocinar más bajo $(P<0.05)$ que las aves control y aquéllas con $5 \%$ SPFP. No se encontraron diferencias en el rendimiento de la carcasa, cortes principales ni en la proporción de carne, hueso y piel. Sin embargo, el porcentaje de grasa abdominal fue menor $(P<0.05)$ para las aves a las que se les suministró $10 \%$ SPFP y mayor en aves del grupo control. Los resultados de este experimento indican que la inclusión de hasta $5 \%$ SPFP en la dieta no tiene efectos detrimentales sobre el desempeño productivo y la calidad de carcasa. EI SPFP podría ser un recurso alimentario útil para suplir parcialmente los requisitos proteicos de la guinea.

Palabras clave: guinea, Numida meleagris, pescado fermentado, calidad de carcasa, peso corporal

\section{INTRODUCTION}

The guinea fowl (Numida meleagris) has been identified as a poultry species suitable for augmenting meat production (Mandal et al., 1999). Despite the fact that genetic improvement of selected commercial lines of guinea fowl has been tremendous, the available lines still cannot compete with the performance of broilers. However, guinea fowl are more tolerant to poor management conditions (Agwunobi and Ekpenyong, 1990), resistant to common poultry diseases (Singh and Panda, 1984), and tolerate aflatoxins better than broilers (Johari et al., 1988). Guineas also provide meat higher in protein, and essential amino acids and lower in fat and cholesterol contents than broilers 
(Cappa and Casati, 1978; Ayorinde et al., 1988; Singh and Raheja, 1990). Thus, guinea meat could be an excellent and healthy alternative for consumers. These characteristics along with the high demand for guinea meat in Puerto Rico make guinea fowl production a promising industry.

On the other hand, production of guinea is more expensive than that of broilers because of the poor feed conversion efficiency and the high cost of keets and feed. In Puerto Rico, feed costs represent about $80 \%$ of the total cost of production since most of the feedstuffs are imported. Furthermore, protein is the most expensive of the major nutrients, and protein requirements of guineas are higher than those of broilers (Blum et al., 1975). Therefore, feedstuffs that provide high quality but less expensive protein could reduce feed costs and benefit production.

A fermented fish by-product meal (FFBPM) using local raw material was developed at the Animal Nutrition Laboratory. It has a nutrient profile similar to that of conventional protein supplements but at a reduced cost. This FFBPM has been used in ruminant diets at daily intakes of up to $0.9 \%$ of animal live weight with no detrimental effect on performance (A. A. Rodríguez, unpublished data). However, the incorporation of this novel feedstuff into diets of non-ruminant animals and its effects on performance needs to be evaluated. In a recent study elsewhere, Magaña et al. (1999) reported that a 15\% dietary inclusion of tuna fish waste silage had no adverse effect on feed intake, weight gain, or feed conversion efficiency of broilers. Thus, our FFBPM could be a potential feed resource to partially replace commonly used ingredients such as corn and soybean meal to meet the protein and energy requirements of guineas, if there is no detrimental effect on performance and carcass quality. The objective of this study was to evaluate the effect of two inclusion levels of a FFBPM in guinea diets on performance and carcass quality.

\section{MATERIALS AND METHODS}

The FFBPM meal was prepared at the Department of Animal Industry Nutrition Laboratory as follows. Fermentation was carried out in plastic containers filled with a mixture of $80 \%$ fish by-product, $20 \%$ cane molasses (as a fermentable carbohydrate source); this mixture was inoculated with a starter culture $\left(10^{6} \mathrm{cfu} / \mathrm{g}\right.$ fresh material $)$ of lacticacid producing bacteria. Containers were sealed with airtight lids; contents were allowed to ferment for $14 \mathrm{~d}$. After fermentation, the mixture was transferred to aluminum pans and dried in an air steam dryer at $65^{\circ} \mathrm{C}$ for $72 \mathrm{~h}$. The dried FFBPM was ground to a particle size of 
TABLE 1. Percentage composition and nutrient content of experimental diets.

\begin{tabular}{|c|c|c|c|c|c|c|c|c|c|}
\hline \multirow[b]{3}{*}{ Ingredient } & \multicolumn{3}{|c|}{ Starter (0-4 wk) } & \multicolumn{3}{|c|}{ Grower (5-8 wk) } & \multicolumn{3}{|c|}{ Finisher (9-12 wk) } \\
\hline & \multicolumn{9}{|c|}{ FFBP Inclusion (\%) } \\
\hline & 0 & 5 & 10 & 0 & 5 & 10 & 0 & 5 & 10 \\
\hline Ground corn & 50.02 & 49.98 & 48.10 & 53.33 & 51.05 & 55.25 & 60.00 & 60.00 & 60.00 \\
\hline Soybean meal & 41.74 & 38.39 & 35.34 & 33.00 & 30.00 & 26.00 & 27.68 & 24.38 & 21.03 \\
\hline FFBP & 0.00 & 5.00 & 10.00 & 0.00 & 5.00 & 10.00 & 0.00 & 5.00 & 10.00 \\
\hline Vegetable oil & 3.65 & 3.02 & 3.01 & 6.31 & 6.43 & 4.36 & 6.37 & 5.71 & 5.06 \\
\hline Dicalcium phosphate & 1.75 & 1.87 & 2.00 & 1.58 & 1.71 & 1.69 & 1.51 & 1.63 & 1.70 \\
\hline $\begin{array}{l}\text { Vitamin and mineral } \\
\text { premix }^{1}\end{array}$ & 0.50 & 0.50 & 0.50 & 0.50 & 0.50 & 0.50 & 0.50 & 0.50 & 0.50 \\
\hline Limestone & 1.74 & 0.64 & 0.00 & 1.80 & 0.69 & 0.00 & 1.41 & 3.14 & 0.00 \\
\hline DL-Methionine & 0.10 & 0.10 & 0.10 & 0.01 & 0.00 & 0.00 & 0.03 & 0.001 & 0.00 \\
\hline Salt & 0.50 & 0.50 & 0.50 & 0.50 & 0.50 & 0.50 & 0.50 & 0.50 & 0.50 \\
\hline \multicolumn{10}{|l|}{ Calculated nutrients } \\
\hline $\mathrm{CP}(\%)$ & 24 & 24 & 24 & 20 & 20 & 20 & 18 & 18 & 18 \\
\hline $\mathrm{ME}(\mathrm{kcal} / \mathrm{kg})$ & 3,050 & 3,050 & 3,050 & 3,180 & 3,180 & 3,180 & 3,280 & 3,280 & 3,280 \\
\hline Crude fat (\%) & 5.78 & 5.89 & 6.56 & 8.44 & 9.23 & 8.06 & 8.69 & 8.77 & 8.87 \\
\hline Crude fiber (\%) & 2.20 & 2.10 & 1.97 & 2.00 & 1.80 & 1.83 & 1.97 & 1.87 & 1.77 \\
\hline $\mathrm{Ca}(\%)$ & 1.10 & 1.10 & 1.28 & 1.07 & 1.07 & 1.20 & 0.90 & 0.90 & 1.19 \\
\hline Total P (\%) & 0.72 & 0.72 & 0.72 & 0.64 & 0.64 & 0.62 & 0.61 & 0.61 & 0.61 \\
\hline Methione (\%) & 0.48 & 0.51 & 0.53 & 0.34 & 0.35 & 0.38 & 0.33 & 0.33 & 0.36 \\
\hline Cysteine (\%) & 0.39 & 0.38 & 0.38 & 0.33 & 0.33 & 0.32 & 0.30 & 0.30 & 0.30 \\
\hline Lysine (\%) & 1.38 & 1.30 & 1.22 & 1.12 & 1.05 & 0.96 & 0.98 & 0.90 & 0.82 \\
\hline
\end{tabular}

${ }^{1}$ Composition of vitamin-mineral premix provided per kilogram of diet: $\mathrm{Fe}, 60 \mathrm{mg} ; \mathrm{Cu}, 5 \mathrm{mg} ; \mathrm{Zn}, 51.4 \mathrm{mg} ; \mathrm{Mn}, 60.8 \mathrm{mg} ; \mathrm{Se}, 0.2 \mathrm{mg} ; \mathrm{I}, 0.6 \mathrm{mg}$; vitamin A, 12,000 IU; cholecalciferol, 3,000 IU; vitamin $\mathrm{E}, 49 \mathrm{IU}$; vitamin $\mathrm{B} 1,2.1 \mathrm{mg}$; vitamin $\mathrm{B} 2,6.6 \mathrm{mg}$; vitamin $\mathrm{B} 6,4.1 \mathrm{mg}$; vitamin $\mathrm{B}_{12}, 20.7$ $\mu$; pantothenic acid, $15 \mathrm{mg}$; nicotinic acid, $36 \mathrm{mg}$; folic acid, $1 \mathrm{mg}$; biotin, $102 \mathrm{mg}$; choline chloride, $700 \mathrm{mg}$; ethoxyquin, $120 \mathrm{mg}$. 
approximately $0.5 \mathrm{~mm}$. A proximate analysis (AOAC, 1990) of the FFBPM revealed that the final product had crude protein and fat contents of 32.0 and $15.5 \%$, respectively.

A three-phase feeding regime, consisting of starter ( 0 to $4 \mathrm{wk})$, grower ( 5 to $8 \mathrm{wk}$ ), and finisher ( 9 to $12 \mathrm{wk}$ ), was used as recommended by Hughes and Jones (1980), Oguntona et al. (1988), and Oguntona and Zubair (1988). The corn- and soybean-based diets were formulated to be isoproteic and isocaloric within each phase of the growing period and to meet or exceed the nutrient requirements for guinea published by earlier researchers (Oguntona et al., 1988; Oguntona and Zubair, 1988; Mandal et al., 1999). The FFBPM was added to the diets to replace part of the corn and soybean ingredients. Treatments (experimental diets) consisted of the inclusion of FFBPM at 0,5 , and $10 \%$ in each of the starter, grower, and finisher diets. Table 1 shows the ingredients and theoretical nutrient composition of each of these diets.

A total of 180 one-day-old guinea keets were raised under standard commercial conditions in a conventional poultry house at the Agricultural Experiment Station Small Animal Research Farm in Lajas. They were divided into 18 replicates of 10 birds each (six per treatment) and randomly assigned to 18 floor pens, each equipped with one hanging tube feeder and nipple-type drinkers and bedded with wood shavings at a stocking density of $0.10 \mathrm{~m}^{2}$. Keets were raised under a 24 -h photo regimen and provided with free access to feed and water for ad-libitum consumption during the entire growing period. Birds and feed were weighed at $0,35,63$, and $84 \mathrm{~d}$ of age to calculate body weight, feed consumption, and feed conversion for each phase of the growing period.

At the end of the experiment, a total of 90 birds were processed to determine carcass composition. The day before processing, five birds randomly chosen per replicate pen for a total of 30 birds per treatment, were wing banded, weighed, and placed in coops $10 \mathrm{~h}$ prior to slaughter without access to feed and water. Birds were hung in metallic funnels and killed by bleeding from a single cut severing the carotid artery and jugular vein. After exsanguinations, birds were scalded, mechanically plucked, weighed, and manually eviscerated. Carcasses were chilled overnight in an ice-slush tank maintained at $0^{\circ} \mathrm{C}$. After being chilled, 10 randomly selected carcasses per treatment were drained, reweighed, and cut into the following portions: wings, drumsticks, thighs, breast with ribs, back, and neck. Carcass parts and abdominal fats were weighted and the yield was expressed as percentage of live body weight.

A completely randomized design was used in the study. Treatments were replicated six times. Each pen of 10 keets constituted an experimental unit. Treatment differences were analyzed for statistical significance 
by analysis of variance (ANOVA) using the General Linear Models (GLM) procedures of SAS® (SAS Institute, 1990). Treatment means showing significant differences in the ANOVA were ranked by using the Tukey's multiple comparison test option of SAS® (SAS Institute, 1990). All statements of significance are based on the probability level of 0.05 .

\section{RESULTS AND DISCUSSION}

\section{Bird Performance}

Data in Table 2 show significant differences among the different levels of inclusion of FFBPM at $35 \mathrm{~d}$ for body weight, weight gain, and feed conversion. At this age, the control and 5\% FFBPM birds had similar but heavier body weights than those fed the 10\% FFBPM diet. The only difference in feed conversion was observed at $35 \mathrm{~d}$ when control birds had better feed conversion than the 10\% FFBPM birds, which had the poorest, whereas those fed the 5\% FFBPM diet did not differ from those

TABLE 2. The effect of FFBPM inclusion at different levels in guinea fowl diets on body weight, feed consumption, body weight gain, and feed conversion. ${ }^{1}$

\begin{tabular}{lcccc}
\hline Parameter & $0 \%$ FFBPM & $5 \%$ FFBPM & 10\% FFBPM & SEM \\
\hline Body weight $(\mathrm{g})$ & & & & \\
$1 \mathrm{~d}$ & 28.8 & 28.8 & 28.0 & 0.26 \\
$35 \mathrm{~d}$ & $761 \mathrm{a}^{2}$ & $730 \mathrm{a}$ & $655 \mathrm{~b}$ & 13.6 \\
$63 \mathrm{~d}$ & 1,377 & 1,368 & 1,255 & 38.7 \\
$84 \mathrm{~d}$ & 1,912 & 1,909 & 1,804 & 30.9 \\
Accumulative feed consumption $(\mathrm{g})$ & & & \\
$35 \mathrm{~d}$ & 1,606 & 1,608 & 1,573 & 59.9 \\
$63 \mathrm{~d}$ & 3,767 & 3,798 & 3,759 & 194.4 \\
$84 \mathrm{~d}$ & 6,361 & 6,475 & 6,470 & 263.4 \\
Accumulative body weight gain (g) & & & \\
$35 \mathrm{~d}$ & $732.4 \mathrm{~b}$ & $701.5 \mathrm{~b}$ & $626.5 \mathrm{a}$ & 13.5 \\
$63 \mathrm{~d}$ & $1,348.0$ & $1,339.4$ & $1,227.3$ & 38.6 \\
$84 \mathrm{~d}$ & $1,883.5$ & $1,880.3$ & $1,776.4$ & 30.8 \\
Accumulative feed conversion (g feed/g body weight) & & \\
$35 \mathrm{~d}$ & $2.19 \mathrm{a}$ & $2.29 \mathrm{ab}$ & $2.51 \mathrm{~b}$ & 0.08 \\
$63 \mathrm{~d}$ & 2.79 & 2.84 & 3.05 & 0.10 \\
$84 \mathrm{~d}$ & 3.37 & 3.44 & 3.71 & 0.11 \\
\hline
\end{tabular}

${ }^{1}$ Values given in this table correspond to least-squares means obtained from ANOVA and their pooled SEM.

${ }^{2}$ Means in a row within a parameter bearing different letters differ significantly at $\mathrm{P}<0.05$. 
of the other treatments. However, at 63 and $84 \mathrm{~d}$ of age these differences were no longer significant. These results are in partial agreement with the observations of Magaña et al. (1999) regarding dietary inclusions of tuna fish waste silage. In their study, a $15 \%$ inclusion had no adverse effects on food intake, weight gain, or feed conversion efficiency of broilers, whereas in the present study only 5\% FFBP could be added without some sacrifice of performance of guinea fowl. Feed consumption at all stages (35, 63, and $84 \mathrm{~d}$ ) was similar for all treatments. Body weight gain showed significant differences only at $35 \mathrm{~d}$ of age, when control and 5\% FFBPM birds had similar but higher gains than those of $10 \%$ FFBPM. No significant differences in weight gain were found at 63 and $84 \mathrm{~d}$, but the same trend was observed. Birds supplemented with $10 \%$ FFBPM had consistently lower body weights than their counterparts. The overall and per phase body weights found in the present study were significantly higher than those observed by Mandal et al. (1999), who found bodyweight gains of $175,276,287$, and $738 \mathrm{~g}$ from 0 to 4,5 to 8,9 to 12 , and 0 to 12 wk of age, respectively, in Pearl guinea broilers. The feed conversions obtained in the present study were also better than those observed by Mandal et al. (1999) of 2.39, 3.54, 5.14, and 3.81 (g feed / g gain) from 0 to 4,5 to 8,9 to12, and 0 to12 wk of age.

\section{Carcass traits}

Table 3 shows live body weight, plucked and dressed carcass weights and their percentages of live weight. There were significant differences among treatments for live body weight and plucked weight. The control and 5\% FFBPM birds had similar but significantly heavier body and plucked weights than birds fed the 10\% FFBPM diets. Dressed carcass weight of control birds was significantly heavier than that of the 10\% FFBPM-fed birds, whereas that of $5 \%$ FFBPM-fed birds was similar to those of the other two treatments. Despite the differences observed among treatments in live body weight, and plucked and dressed carcass weights, dressed carcass yield did not differ among treatments and averaged $69.3 \%$. This yield is comparable to the values of $68.0 \%$ and $67 \%$ obtained by Hughes and Jones (1980) and Agwunobi and Ekpenyong (1990), respectively, but greater than the yield of 52.8\% reported by Ayeni (1980).

Table 4 shows the percentage of carcass cuts and abdominal fat relative to live body weight. No significant differences in carcass cut yield were observed among treatments. Breast, wing, thigh, and drumstick yields averaged $22.81,18.69,13.45$, and $9.50 \%$, respectively. These yields are considerably higher than those reported by Agwunobi and Ekpenyong (1990): $16.0 \%$ breast; $8.6 \%$ wing; and $18.0 \%$ leg obtained in 
TABLE 3. The effect of FFBPM included at different levels in guinea fowl diets on live body weight, plucked weight, dressed weight, and percentage plucked and dressed yield.1,2

\begin{tabular}{lcccc}
\hline Parameter & $\begin{array}{c}0 \% \\
\text { FFBPM }\end{array}$ & $\begin{array}{c}5 \% \\
\text { FFBPM }\end{array}$ & $\begin{array}{c}10 \% \\
\text { FFBPM }\end{array}$ & SEM \\
\hline Live body weight $^{3}(\mathrm{~g})$ & $1,874 \mathrm{a}^{4}$ & $1,839 \mathrm{a}$ & $1,759 \mathrm{~b}$ & 20.4 \\
Plucked weight $^{5}(\mathrm{~g})$ & $1,714 \mathrm{a}$ & $1,682 \mathrm{a}$ & $1,607 \mathrm{~b}$ & 20.0 \\
Dressed weight $^{6}(\mathrm{~g})$ & $1,370 \mathrm{a}$ & $1,335 \mathrm{ab}$ & $1,279 \mathrm{~b}$ & 17.7 \\
Plucked yield $^{(\%)}$ & 91.44 & 91.54 & 91.36 & 0.46 \\
Dressed yield $^{8}(\%)$ & 69.99 & 69.24 & 69.69 & 0.33 \\
\hline
\end{tabular}

${ }^{1}$ Values given in this table correspond to least-squares means obtained from ANOVA and their pooled SEM.

${ }^{2} \mathrm{n}=30$ birds per mean.

${ }^{s}$ Body weight prior to slaughter, following feed and water deprivation for $10 \mathrm{~h}$.

${ }^{4}$ Means in a row within a parameter bearing different letters differ significantly at $\mathrm{P}<$ 0.05 .

${ }^{5}$ Carcass weight after exsanguination prior to evisceration with legs and neck left in the carcass.

${ }^{6}$ Without giblets but with abdominal fat pad left in the carcass.

7Plucked carcass weight/live BW after feed and water deprivation $\times 100$.

${ }^{8}$ Hot carcass weight/live BW after feed and water deprivation $\times 100$.

guineas processed at $12 \mathrm{wk}$ of age. This variability might be attributed to differences in genetic strains, nutrition, and management used in the two studies.

There were significant differences in abdominal fat observed among treatments (Table 4). Control birds had a significantly higher proportion of abdominal fats than birds fed $10 \%$ FFBPM, whereas those fed $5 \%$

TABLE 4. The effect of FFBPM included at different levels in guinea fowl diets on carcass cuts and abdominal fat yields as percentage of live weight., ${ }^{1,2}$

\begin{tabular}{lcccl}
\hline Parameter & $0 \%$ & $5 \%$ & $10 \%$ & \\
& FFBPM & FFBPM & FFBPM & SEM \\
\hline Neck & 5.08 & 5.17 & 5.20 & 0.067 \\
Back & 16.55 & 16.77 & 16.36 & 0.253 \\
Wing & 18.49 & 17.91 & 19.66 & 0.855 \\
Thigh & 13.48 & 13.11 & 13.77 & 0.244 \\
Drumstick & 9.49 & 9.53 & 9.49 & 0.139 \\
Breast & 23.15 & 22.75 & 22.54 & 0.221 \\
Abdominal fat & $1.84 \mathrm{a}^{3}$ & $1.75 \mathrm{ab}$ & $1.37 \mathrm{~b}$ & 0.121 \\
\hline
\end{tabular}

${ }^{1}$ Values given in this table correspond to least-squares means obtained from ANOVA and their pooled SEM.

${ }^{2} \mathrm{n}=10$ birds per mean.

${ }^{3}$ Means in a row within a parameter bearing different letters differ significantly at $\mathrm{P}<0.05$. 
FFBPM had an intermediate percentage not differing from the other treatments. Furthermore, there was a significant negative linear response in the proportion of abdominal fats with increasing levels of FFBPM inclusion. The percentage of abdominal fats decreased from $1.84 \%$ to $1.37 \%$ of live weight as the level of FFBPM increased in the diet.

Table 5 shows the effect of dietary FFBPM inclusion on proportions of skin, bone and flesh in breast, thigh, and drumstick. These proportions did not differ among treatments for the thigh and drumstick carcass parts. Only in the breast was the proportion of skin significantly lower in birds fed 10\% FFBPM compared to that of the other two treatments. The fact that these birds also had significantly lower deposition of abdominal fat in the carcass may help to explain this result as fat is also deposited subcutaneously and may remain attached when the skin is removed.

From the present results it can be concluded that a dietary level of $5 \%$ FFBPM allows a productive performance and carcass quality comparable to that of the control, whereas the 10\% level of FFBPM is less satisfactory. This FFBPM could supply part of the protein now provided by imported soybean meal without affecting productive performance and carcass composition.

TABLE 5. The effect of FFBPM included at different levels in guinea fowl diets on breast, thigh, and drumstick proportion of skin, bone and flesh. ${ }^{1,2}$

\begin{tabular}{ccccc}
\hline \multirow{3}{*}{ Cut } & $0 \%$ & $5 \%$ & $10 \%$ & \\
& FFBPM & FFBPM & FFBPM & SEM \\
\hline
\end{tabular}

Breast

$\begin{array}{lllcl}\text { Skin } & 11.91 \mathrm{a}^{3} & 12.97 \mathrm{a} & 9.20 \mathrm{~b} & 0.739 \\ \text { Bone } & 19.88 & 19.80 & 20.32 & 1.077 \\ \text { Flesh } & 66.61 & 66.06 & 68.96 & 1.287 \\ \text { Thigh } & & & & \\ \text { Skin } & 14.41 & 14.64 & 11.68 & 1.019 \\ \text { Bone } & 11.90 & 14.04 & 13.82 & 0.654 \\ \text { Flesh } & 72.73 & 68.07 & 74.91 & 2.310 \\ \text { Drumstick } & & & & \\ \text { Skin } & 10.32 & 9.35 & 8.68 & 0.934 \\ \text { Bone } & 23.19 & 23.71 & 22.83 & 1.691 \\ \text { Flesh } & 65.44 & 67.03 & 66.27 & 1.536\end{array}$

${ }^{1}$ Values given in this table correspond to least-squares means obtained from ANOVA and their pooled SEM.

${ }^{2} \mathrm{n}=10$ birds per mean.

${ }^{8}$ Means in a row within a parameter bearing different letters differ significantly at $\mathrm{P}<$ 0.05 . 


\section{LITERATURE CITED}

Agwunobi, L. N. and T. E. Ekpenyong, 1990. Nutritive and economic value of guinea fowl (Numida meleagris) production in developing countries. J. Food. Agric. 50:301308.

Association of Official Analytical Chemists (AOAC), 1990. Official Methods of Analysis. Williams, J. (ed). Arlington, VA.

Ayeni, J. S., 1980. The biology and utilization of the helmeted guineafowl (Numida meleagris galeata pallas) in Nigeria. Ph.D. Thesis, University of Ibadan.

Ayorinde, K. L., J. A. Oluyemi and J. S. Hallen, 1988. Growth performance of four indigenous helmeted guineafowl varieties (Numida meleagris galeata pallas) in Nigeria. Bull. Anim. Health Prod. Africa. 36:356-360.

Blum, J. C., J. Guillaume and B. Lecterco, 1975. Studies of the energy and protein requirements of the growing guinea fowl. Br. Poultry Sci. 16:157-168.

Cappa, V. and M. Casati, 1978. Experiments of growing guinea fowl, amino acid composition of the carcass. Avicoultura. 47(3):21-29.

Hughes, B. L. and J. E. Jones, 1980. Diet regimes for growing guineas as meat bird. Poultry Sci. 59:582-584.

Johari, T. S., S. K. Agarwal, V. R. Sadagopan, and H. Singh, 1988. Effect of dietary afflatoxin on the performance of guinea fowl. Ind. J. Anim. Sci. 58:873-875.

Magaña-Vizcarra, L. A., E. Avila and A. Sotelo, 1999. Silage preparation from tuna fish wastes and its nutritional evaluation in broilers. J. Sci. Food Agric. 79:1915-1922.

Mandal, A. B., N. N. Pathak and H. Singh, 1999. Energy and protein requirements of guinea keets (Numida meleagris) as meat bird in a hot humid climate. J. Sci. Food Agric. 79:523-531.

Oguntona, T., M. Raheenat and A. K. Zubair, 1988. Effects of beak trimming at different ages on the body weight and feed conversion of guinea fowl (Numida meleagris). Poultry Sci. 67:141-144.

Oguntona, T. and A. K. Zubair, 1988. Response of guinea fowl (Numida meleagris) to dietary supplementation of zinc bacitracin. Poultry Sci. 67:145-148.

SAS Institute, 1990. SAS® / STAT guide for personal computers. Version 6.12 edition. SAS Institute Inc. Cary, NC.

Singh, H. and B. K. Panda, 1984. Guinea fowl health cover requirements and common disease. Poultry Guide 21(12):39-43.

Singh, H. and K. L. Raheja, 1990. Genetic estimates of cholesterol and high density lipid components in indigenous guineafowl serum. In: Proceedings of XIII Annual Conference and Symposium of Indian Poultry Science Association. Bombay Vety College, Bombay, India. 